Prace Literackie LVIII

Wrocław 2018

https://doi.org/10.19195/0079-4767.58.12

\author{
ANETA MAZUR \\ ORCID: 0000-0002-8850-3571 \\ Uniwersytet Opolski
}

\title{
Śródziemnomorskie kody polskości w twórczości Jana Parandowskiego
}

Z Janem Parandowskim zawsze był kłopot - jego misja maga i kustosza antycznego świata nie budziła pełnego zaufania. W epoce PRL-u bywał to strofowany za niezaangażowanie we współczesność ${ }^{1}$, to nagradzany za nieszkodliwą apolityczność ${ }^{2}$. Podkreślano jego dumne obywatelstwo Polski leżącej nad Morzem Śródziemnym ${ }^{3}$, obronę uniwersalnej kultury europejskiej, ale i uprzywilejowaną kondycję chętnie publikowanego kandydata (,w miejsce” Herberta) do Nobla in spe.

Sam pisarz nie identyfikował się z zarzucaną mu postawą olimpijczyka: „Nie wydaje mi się, abym [...] zdradzał nasze czasy. [...] nic nie jest bardziej współczesne od greckiej myśli i greckiego piękna”4 "Nie antyk sam w sobie, lecz humanizm był ideałem ojca — sekundował mu Piotr Parandowski — powstała Polska i należało ją edukować”. Jednak w opracowaniach czytamy: „Parandowski ma

1 „W bardzo trudnych latach powojennych dawną etykietę olimpijczyka, nieszkodliwą w istocie, liczni »zaangażowani« zastąpili określaniem ojca jako pisarza apolitycznego" — P. Parandowski, Mitologia wspomnień, Warszawa 2008, s. 98.

2 „Parandowski nie należy do ulubieńców obecnego reżymu w Polsce, ale ponieważ jest powszechnie szanowany w kręgach literackich, nie jest też przez władze atakowany” — pisał dobrze zorientowany obywatel Izraela w 1952 roku; zob. E. Kossewska, Hebrajski przekład „,Mitologii”. Listy Jana Parandowskiego, Dawida Lazera i Dawida Ben Guriona, „Pamiętnik Literacki” 2018, z. 2, s. 204.

${ }^{3}$ Tak zatytułowany wykład wygłosił Parandowski w 1937 roku — Pologne est située sur la Méditerranée; przekład polski: J. Parandowski, Polska leży nad Morzem Śródziemnym, „Przegląd Polski - Polish Review" 14.12.1989.

${ }^{4}$ J. Parandowski, Antyk i ja, [w:] Wspomnienia i sylwety, Wrocław 1969, s. 201; dalej pozycję tę oznaczam skrótem Wis wraz z numerem strony.

5 P. Parandowski, Powstała Polska i należało ją edukować, [w:] Godzina śródziemnomorska, „Studia Classica et Neolatina” 2, Gdańsk 1995, s. 7. 
dwie ojczyzny — jedna to antyk grecko-rzymski, druga — lata fin de siècle'u"', „W jego biografii twórczej problem niepodległości praktycznie nie występuje"7; „polskość $[\ldots]$ nie jest [...] ważnym tematem jego dyskursu”». Paradoksalnie, opcja ponowoczesna, też nieufna wobec autora Mitologii, pogodziła obie racje, twierdząc, że „fetysz antycznego świata” umożliwia „nostalgiczne bezpieczeństwo" wobec „niepokojącej współczesności”.

Biorący udział w tym cichym sporze wydają się zapominać, że pisarz odszedł przed październikiem 1978, sierpniem 1980, czerwcem 1989 roku — odszedł w milczeniu, skazany na niedomówienia ${ }^{10}$. Mówi za to jego proza. Polskość uobecnia się w niej przede wszystkim kulturowo, w mniejszym stopniu etnicznie i historiozoficznie, a w znikomym — politycznie. Jest dyskretna — zdystansowana, lecz rzadko ironiczna; patetyczna, ale powściągliwie. Dystans wynikał z antropologicznej wyobraźni pisarza, filozofa kultury; w jego wizji, zabarwionej egzystencjalnym personalizmem i szczyptą bergsonowskiego mistycyzmu ${ }^{11}$, Polska była tylko wycinkiem długiego łańcucha zadziwiającej wspólnoty Homo sapiens, od zarania po nieznaną jeszcze przyszłość „zamkniętych drzwi czasu”12. Tonacja kodów polskości u Parandowskiego, od jawnych po hipotetyczne, koresponduje z epokami jego historycznie bogatej biografii. I choć najłatwiej kojarzyć je z ,alchemią" języka oraz śródziemnomorskim szlifem naszej kultury, warto uruchomić właśnie chronologiczno-typologiczny ogląd problemu.

${ }^{6}$ W. Studencki, Alchemik słowa. Rzecz o Janie Parandowskim, cz. 2, Opole 1974, s. 79. Autor powtarza sąd Jacka Susuła (z: Jan Parandowski, „Tygodnik Powszechny” 1967, nr 30). Sam pisarz upomniałby się pewnie o trzecią ojczyznę, Francję; deklarował w tej kwestii wspólnotę z Tadeuszem Boyem-Żeleńskim.

7 J. Okoń, Sarbiewski a Parandowski - dwie rocznice, dwie tradycje, „Ruch Literacki” 1996, z. 4 , s. 398 .

${ }^{8}$ R. Szczerbakiewicz, „Niepokalana szczerość jest urojeniem”. Dekonstrukcje mitu śródziemnomorskiego w twórczości Jana Parandowskiego, Lublin 2014, s. 167-168.

${ }^{9}$ Ibidem, s. 83, 197.

10 Podobną nieadekwatność zarzutów, przechodzących do porządku nad faktami, sugerował Piotr Parandowski, zestawiając pretensje do ojca z zarzutami Gombrowicza pod adresem Nałkowskiej i z napomnieniami Polaków przez Marcina Króla w 1989 roku — w obu wypadkach chodzi o krytykę polskiej europejskości, która jest albo „imitowana”, albo mieści się „,poza europejską normą" w wyniku degrengolady w systemie ,lichego cesarstwa Moskwy”. Tak formułowane zarzuty wobec elit - które nie wstydząc się swojej polskości, nie czuły się także „ani przez chwilę” poza Europą - autor nazywa „uproszczeniem intelektualnym” - P. Parandowski, op. cit., s. 97-98.

11 Jan Prokop widział w klasycyzmie generacji Parandowskiego ,wcielenie poszukującego ładu witalizmu" - idem, Prozaicy dwudziestolecia międzywojennego. Sylwetki, red. B. Faron, Warszawa 1974, s. 484.

12 „Każdy z nas jest ogniwem w łańcuchu długiej i dalekiej historii, nieznanej ani w swych początkach, ani w swoim biegu - J. Parandowski, Pod zamkniętymi drzwiami czasu, Warszawa 1975, s. 7. 


\section{Dziewiętnastowieczność zaborowa - wielkość romantyków, ale bez przesady}

Twórczość autora Nieba w płomieniach (1936) rejestruje ostatnie ślady Polski romantyczno-powstańczej i pozytywistyczno-organicznikowskiej. Oto lwowski ekspowstaniec i malarz Ludomir Benedyktowicz z przejęciem świętuje rocznicę w 1913 roku, a także potem, „gdy wzeszła tak upragniona, a tak daleka, poza wszelką nadzieją i rachubą ludzką, Polska"13. Oto proboszcz bernardynów, miłośnik motyli, z wędrówek po Galicji i Królestwie przynosi nowe okazy do swej kolekcji oraz inspirację do płomiennych niepodległościowych kazań: „Teraz miał w oczach całą Polskę, w sercu gorycz. Ten cudowny kraj, rozdarty między trzy państwa, mówił do niego [...] wrzącą miłością wolności"14. Emocjonalna żarliwość sformułowań to raczej perspektywa samych powstańców, choć w latach sześćdziesiątych mogła być też mową ezopową autora. Weterani stycznia najczęściej pojawiają się we wspomnieniach pisarza nie jako bohaterowie walk, lecz zasłużeni pracownicy cywilizacji, „,indywidualności o niepospolitej energii, przedsiębiorcze" 15 . W relikwiarzu pamięci zapisze się także dotykalna obecność wielkich XIX stulecia: bolesne przeżycie ucznia, gdy nauczyciel „nie pozwolił stanąć w szpalerze, jak przejeżdżał Sienkiewicz”, i odziedziczone po starym pokoleniu wspomnienie „dobrego człowieka” Kraszewskiego ${ }^{16}$.

Dziewiętnastowieczna polskość u Parandowskiego prawie nie wykazuje rysów martyrologicznych. Tylko gdzieś w tle przesuwa się postać nauczyciela unity, który „uciekł przed prawosławnymi prześladowaniami”17, a relacja z wizyty w Wiedniu lat pięćdziesiątych nieoczekiwanie zabarwi się idiosynkrazją: ,jednak nie umiem się wciąż pozbyć urazy [...] do stolicy zaborczego państwa. Nawet te czarno-żółte skrzynki pocztowe mnie drażnią" ${ }^{18}$. Niebo $w$ płomieniach rzetelnie oddaje lwowską atmosferę u kresu monarchii — rekolekcje, „gdzie głos Ewangelii mieszał się z cytatami poetów”, akademie, na których się „czci ojczyznę jak Boga”, a także tę „dziwną ówczesną atmosferę magnetyczną, rozkwitającą za lada podmuchem w biało-czerwone zorze borealne" — lecz w autobiograficznej

13 J. Parandowski, Akacja, Warszawa 1967, s. 12.

14 J. Parandowski, Zlota nić, Kraków 1988, s. 133-134.

15 J. Parandowski, Dzieła wybrane, Warszawa 1957, t. 3, s. 450; dalej wydanie to oznaczam skrótem DW, rzymska cyfra oznacza tom, arabska — stronę.

${ }^{16}$ DW II, 686, 697.

17 DW II, 711.

18 Wis, 264. Jakby na przekór idiosynkrazjom pisarza Jakub Zdzisław Lichański osadza jego twórczość w kontekście austriackiego modernizmu (Musil, Broch, Doderer, Hofmannsthal, Schnitzler, Rilke, Kraus) - eklektycznego kulturowo i otwartego na antyk, w przeciwieństwie do modernizmu francuskiego; zob. idem, Wtajemniczenia i refleksje. Szkic monograficzny o Janie Parandowskim, Łódź 1986, s. 11. 
narracji wyczuwalna jest rezerwa ${ }^{19}$. Bohater uchyli się od udziału w konspiracji, a wysublimowane projekcje polskości poda w wątpliwość jego ojciec:

Wydaje ci się niegodnym mówić o Polsce w knajpie, ponieważ w Twojej głowie istnieje Polska taka niematerialna, że boisz się ją spłoszyć stuknięciem widelca o talerz. [...] A już żeby w tej Polsce miał być policjant i, nie daj Boże, kryminał — któż się odważy pomyśleć, że Chrystus narodów wprowadzi ze sobą do raju taką hołotę! ${ }^{20}$

Dyskurs radcy o polskości, nazwany „spowiedzią o Polsce”, zawiera zdanie: „Ojczyzna to straszna rzecz, [...] w tych warunkach, w jakich żyjemy”21. Chodzi o ponoszone ofiary, aczkolwiek w kontekście całego utworu to jakby też aluzja do niemożności wysłowienia tej ojczyzny ${ }^{22}$.

Ambiwalentny, złożony stosunek klasyka do tradycji romantycznej nie był tylko kwestią dystansu czasowego. „Dziedzictwo... Byliśmy wykołysani, wychowani poezją narodową”; „Czy podobna Polakowi uniknąć romantyzmu? Zbyt wiele on dla nas znaczył" - wyznawał w połowie XX wieku ${ }^{23}$. Wizję problematycznego spadku zawiera też imaginacyjna Rozmowa z cieniem:

— Piotr: [...] Poezja w tym kraju [...] stworzyła [...] nową historię, piękniejszą, wspanialszą, a może i prawdziwszą od rzeczywistej [...]. Piękno, które stworzono wtedy, tysiącem włókien przenikało w życie narodu. [...]

- Horacy: Gdzież jest ten naród i jego ziemia?

— Piotr: Stoisz na niej, Horacy.

- Horacy: Zazdroszczę ci, warto mieć za sobą takie dzieje.

— Piotr: A my najczęściej widzimy w nich nieudźwignione brzemię ${ }^{24}$.

$\mathrm{Na}$ ile bliska/obca była pisarzowi idea mesjanizmu? Czy na emocjonalny stosunek do romantyzmu wpłynął kontekst (po)wojenny? Przedwojenny Parandowski był surowszy; w jubileuszowym roku Kochanowskiego (1930) zwrócił uwage na szkody, jakie odniosła kultura polska pozbawiona płynnej ciągłości:

19 DW I, 499-500, 673, 680. Mowa jest na przykład o wygłaszanych na akademii „,banałach”, błąkanie się wśród lwowskich „nieszczęsnych "pamiątek historycznych«" nie rozprasza „nudy” bohatera, a komentarz dotyczący polonisty, członka „Sokoła”, jest dobrotliwie ironiczny: „W niczyich ustach wyraz »Polska« nie brzmiał tak szlachetnie, nikt również nie używał go tak często. Tym słowem umiał on budzić z uśpienia umysły [...]. Polonista (druh-sokół) znał się na »uczuciu«" DW I, 476, 563-564, 670, 673.

${ }^{20}$ DW I, 681.

${ }^{21}$ DW I, 506, 707.

${ }^{22}$ Symboliczne jest przerwanie rozmowy ojca i syna o Polsce — już więcej nie podjętej — na zamilknięciu wzruszonego Teofila: „Jakże mało wiedział o tym człowieku! Jakże niesłusznie go lekceważył! [...] — Tatusiu, [...] proszę mi powiedzieć... [...] Gardło zdusił kurczowy uścisk, niewymówione słowa zamarły" — DW I, 682.

${ }^{23}$ Wis, 191; DW III, 454. „O polskich romantykach mówił przez łzy. [...] Pamiętam audycję Polskiego Radia w latach sześćdziesiątych, kiedy fragment prozy ojca połączono ze Słowackim. »Większej nagrody nie chcę« — powiedział" — P. Parandowski, op. cit., s. 178.

${ }^{24}$ DW II, 543. 
Romantyzm. Nowa i oszałamiająca poezja, która objęła całą aktualność uczuciową Polski, odcięła nadchodzące pokolenia od starej [...] żyjemy do dziś tak, jakby nasza literatura zaczęła się dopiero w wieku XIX ${ }^{25}$.

Inna zamaskowana krytyka - w ,ideowym gazdostwie [kultury renesansu] dojrzewa patriotyzm męski, trzeźwy, spokojny, oparty nie o miraż i patos, lecz o węgły wolnego państwa”26. I jeszcze szpileczka wetknięta „entuzjastom naszej wielkiej trójcy z dodatkiem Wyspiańskiego. Było niejako prawem, że ubliżałoby się ich wielkości, mówiąc o nich bardziej prostym językiem i nie zaglądając każdym zdaniem w przepastne głębiny"27.

No cóż, klasyk nie znosi przesady.

\section{Dwudziestolecie - Polska nad Morzem Śródziemnym}

Nie przypadkiem najbardziej znany kod polskości Parandowski rozwija w epoce międzywojennej, jakby razem ze skamandrytami chciał widzieć głównie wiosnę. Zakończenie Dwóch [notabene] wiosen (1927) jest wymowne: „Nikną gorące westchnienia mórz południowych i [...] podnosi się z szerokości, z zapachem bzów zmieszana, $[\ldots]$ ogromna polska wiosna" 28 . Pisarz nie odnotuje wydarzeń wojennych, których był świadkiem we Lwowie lat 1919-192029. Portret młodej niepodległości wzbogaci później jeszcze tylko echem ówczesnej euforii: „dokonało się to, o czym śnił, za czym tęsknił w żarliwej rozpaczy autor Irydiona"30; „Był to już inny świat — w promieniach wolności, w trzepocie biało-czerwonych flag, $[\ldots]$ wesoły, rozśpiewany i roztańczony, kobiety zrzuciły długie suknie, jakby wszystkie zamieniły się w podlotki" ${ }^{31}$. W tym rozśpiewanym świecie autor Mitologii skarży się w listach na prowincjonalizm Lwowa, marzy o kolejnych podróżach na południe, a przede wszystkim zaczyna tworzyć swój „intencjonalny projekt”: „uwewnętrznioną fantazję"32 polsko-śródziemnomorską.

Patronuje jej „wspaniała postać Europejczyka”, należącego „do tych północnych natur, które mają swe tajemnicze korzenie na południu" - Tadeusza Zielińskiego, u którego Parandowski podziwiał „giętkość umysłu, która z uczo-

${ }^{25}$ DW III, 90. Wyjątek czynił Parandowski dla Sienkiewicza i Żeromskiego, pozostających w „niezachwianej harmonii” z całą historią języka polskiego.

${ }^{26}$ DW III, 93.

27 Wis, 99.

28 DW II, 233.

${ }^{29}$ Dopiero po latach pojawią się przygodne wzmianki: „,biało-czerwony sztandar witał się z listopadowym niebem, biliśmy się o Lwów”; „burzliwe dni” 1919 roku — DW II, 460; J. Parandowski, Podróże literackie, Wrocław 1968, s. 103.

${ }^{30}$ Wis, 192. Jak wspomina Parandowski, w latach pięćdziesiątych w Warszawie był dostępny ,jedyny [!] egzemplarz” Nie-boskiej komedii - Wis, 193.

31 J. Parandowski, Akacja..., s. 69.

${ }^{32}$ R. Szczerbakiewicz, op. cit., s. 385, 409. Oczywiście dla postmodernisty to „kolonialna zależność prowincji kontynentu od kulturowego imperializmu łacińskiej Europy" - ibidem, s. 396. 
nego czyni artystę"33. I sam właśnie jako „uczony artysta” będzie całymi latami tropił ślady Polski śródziemnomorskiej: od refleksji nad „najstarszym w pamięci ludzkiej miastem polskim" "34 i dziejowym wpisem łacińskim Mesco, dux Poloniae, baptizatur, przez przyrównanie smętnego ubóstwa pejzaży Mazowsza i Grecji, po dumną apologię renesansu (,jedyny moment, kiedy Polska stoi na równi kulturalnej z najbardziej oświeconymi narodami" ${ }^{35}$ ). I - w Trzech znakach zodiaku, Moim Rzymie, $W$ antycznym świecie — od niewolnika z północy, o „włosach płowych, oczach niebieskich”36, w rzymskich kamieniołomach, poprzez hipotetyczne spotkanie Łokietka i Dantego w Rzymie AD 1300, poprzez galerię zasłużonych Polaków średniowiecza i renesansu (święty Stanisław, Kopernik, Klemens Janicki, Kochanowski, Górnicki), po filologiczną misję Ossolineum oraz łowickich pielgrzymów na audiencji u papieża. Tropi te same ślady, broniąc Stanisława Augusta (,z powrotem zeuropeizował Polskę, którą zastał na głuchym pustkowiu Wschodu"37) i planując powieść piastowską z XIII wieku ${ }^{38}$. Jeszcze inaczej wchodzi w bliską, intymną wręcz komunię ze Śródziemnomorzem narrator-pielgrzym Dwóch wiosen - witając „Salaminę, bo na jej wodach rozstrzygnęły się kiedyś ich i nasze losy”, kłaniając się „od kurhanów Dzikich Pól [...] promiennemu słońcu Temistoklesa" i spoglądając na siebie oczyma świata antycznego: „Oto ja, [...] człowiek z krajów, których twoi ludzie nie znali nawet z bajki”39. Trzeba się jednak zgodzić z Rafałem Szczerbakiewiczem, że polsko-śródziemnomorskich związków nie jest znowu w tej twórczości tak wiele, choć nie warto godzić się z jego tezą, iż mit śródziemnomorski był „,permanentnym i opresyjnym, lecz równocześnie niezbędnym i pożądanym kagańcem, nakładanym sobie przez społeczeństwo" 40 — ten kaganiec bowiem często dostarczał na-

${ }^{33}$ DW III, 71, 78, 79.

34 DW II, 438. Chodzi oczywiście o Kalisz identyfikowany z rzymską nazwą Calisia.

35 Wis, 175. Pisarz kreuje rodzaj literacko-państwowej utopii Polski renesansowej, wielkiej „,nie tylko siłą i dobrobytem państwa, świetnym pocztem ludzi” oraz „szeregiem rewolucyjnych odkryć w zakresie humanitaryzmu, opieki nad godnością ludzką, troski o świętość prawa”, lecz także z racji wolności - „najżywotniejszego ideału ówczesnej Europy, nigdzie w tym stopniu nie urzeczywistnionego”. Również „literatura tych czasów [...] wyprzedza niejedną instytucję”, a humanizm Kochanowskiego „treść rdzennie polską czynił zrozumiałą na każdym równoleżniku świata cywilizowanego" - DW III, 87, 92-93.

36 DW II, 312 .

37 Wis, 188.

38 Ciekawe, że polskość Parandowskiego w ogóle jest bardziej piastowska niż jagiellońska, bliska Jasienicy, a obca rzymsko-sarmackiej tradycji ziemiańskiej, niemal wykluczonej na rzecz ludowej, mieszczańskiej czy inteligenckiej. Może tym należałoby tłumaczyć rezerwę wobec historycznego wizjonerstwa Sienkiewicza, adorowanego głównie jako mistrz słowa, nieobecnego na sporządzonej przez pisarza liście Moi towarzysze: „Homer, Platon, Horacy, Tacyt, Dante, Petrarka, Szekspir, Ibsen, Goethe, Kochanowski, Mickiewicz, Słowacki, Schopenhauer, Żeromski, Flaubert, Conrad" - P. Parandowski, op. cit., s. 183.

${ }^{39}$ DW II, 146, 200.

${ }^{40}$ R. Szczerbakiewicz, op. cit., s. 169. 
miastek wolności. Parandowski mówił o śródziemnomorskiej glebie polskości, ale było to sprzężenie zwrotne - ileż studiów nie powstałoby bez tragicznego podglebia polskiej historii; dodatkowo uspokajająca praca nad przekładem $O d y$ sei pomagała przetrwać lata stalinowskie.

W dywagacjach przedwojennych pojawiają się jeszcze dwa istotne dyskursy narodowe. Pierwszy to polemika z autorem głośnej Zdrady klerków (1928), którego tezę o zgubnym, nowoczesnym nacjonalizmie Parandowski odrzuca:

Uważam bowiem patriotyzm za uczucie naturalne, godziwe, nieuchybiające stanowisku klerka. $[\ldots]$ jest $[\ldots]$ niejako rozszerzonym uczuciem rodzinnym. $[\ldots]$ stopniowanie sympatii $[\ldots]$ widoczne w bliskim kręgu, istnieje w najszerszym, w stosunku do swego narodu i reszty świata. [...] wytrzebienie tych uczuć nie przyniosłoby ludzkości pożytku. Nawet duma narodowa nie jest naganna, jeśli opiera się na wywyższeniu cech istotnie godnych pochwały ${ }^{41}$.

Nieoczekiwanie, zza grobu, ,olimpijski” intelektualista zabiera głos w dzisiejszej dyskusji europejskich „elit” i „populistów”. Staje po stronie tych ostatnich — już wtedy zresztą był świadomy, że czeka go „ekskomunika, którą p. Benda strąci [go] między zepsutych klerków"42.

Dyskurs drugi to wątek conradowski, zainicjowany szkicem Przymierze z morzem (1938), a kontynuowany w noweli o słynnym tytule Godzina śródziemnomorska (1941) oraz w portrecie Conrad (1948). Motywy fascynacji pisarza wielkim rodakiem są oczywiste: uniwersalizm przygód w egzotycznych pejzażach mórz świata i w tajemniczym pejzażu ludzkiego Mare Tenebrarum, romantyczny kod polskości i refleksyjny humanizm, „dyskrecja intelektualna i uczuciowa”, typ fikcji złożonej „z trzech elementów: obserwacji, pamięci faktów życiowych, fantazji”, no i oczywiście ,jedna z najbardziej fascynujących zagadek w dziejach sztuki słowa [...]. Conrad zakochał się w języku angielskim" "43. Parandowski wydaje się jednak także zafrapowany trudną relacją Korzeniowskiego z polskością. $\mathrm{Z}$ goryczą wytyka rodakom (w końcu lat czterdziestych) zaniedbanie recepcji pisarza, ze współczuciem pisze o jego samotności i „próbach wejścia czy powrotu w świat polski”, o rozrachunkach, które mu w tej kwestii wytaczano i które wytaczał sobie sam. Krytycznie odnosi się do szans spełnienia jego talentu w języku ojczystym w dobie, kiedy święciła triumfy literatura krzepiąca serca: „Nie trudno sobie odtworzyć przyjęcie, jakie by groziło Szaleństwu Almayera i Wygnańcowi, książkom tak oderwanym od naszego świata. Egzotykę można było uprawiać tylko za cenę zesłania, jak Sieroszewski" ${ }^{44}$.

Wątek conradowski służy pisarzowi do - wyjątkowej w jego twórczości polemiki z polskością krępującą i niewolącą. W Godzinie śródziemnomorskiej, w imaginacyjnym, pirandellowskim dialogu starego Conrada z bohaterem Kor-

${ }^{41}$ DW III, 133-134.

42 DW III, 134.

${ }^{43}$ DW III, 458, 460, 462, 463.

44 „W postawie obu [...] było polskie przymierze ze wszystkim, co na świecie odsunięte i upośledzone przez przemoc" - DW III, 459, 461, 464. 
sarza Peyrolem dochodzi do konfrontacji dwóch pełnoprawnych racji: lojalności wobec własnego narodu oraz wierności swojemu powołaniu ${ }^{45}$. Tytuł noweli, niezbyt uzasadniony fabularnie, a precyzyjnie odsyłający do twórczości Parandowskiego, mógłby sugerować kamuflaż jego własnych, podświadomych lęków, a identyfikacja z fikcyjnym Conradem — rodzaj autorefleksji. W wojennym roku 1942 mogło to być istotne dla pisarza uciekającego w świat kultury przed osaczającą go grozą.

\section{Okupacja - mapowanie Polski}

Ojczyzna jest abstrakcją. Jeśli ma się zarysować w wyobrażeniu, musi szukać swego kształtu w przedmiotach konkretnych. Jeden na dźwięk tego słowa zobaczy mapę, chorągiew [...] lub jakiś inny symbol, dla drugich zacieśni się ona w pierwszym błysku wyobraźni w jakiś skrawek ziemi rodzinnej [...]. Należę do tej drugiej grupy ${ }^{46}$.

Proustowska epifania była stałym komponentem poetyki Parandowskiego, jej manifest w kontekście wspomnień wojennych potwierdza tylko dyskrecję autora w wyrażaniu ówczesnych emocji. Zostają one przełożone na opis polskiego pejzażu, w którym błądzą (po)wojenni tułacze. Synestezyjne impresje na wzór magdalenki uruchamiają jednak polskość archetypiczną i tysiącletnią:

Jakby to było zaklęcie, słowo: dwunasta, niesione na dźwiękach wiejskiego dzwonu, urzekło świat zmysłów i świadomości. Posłyszane dźwięki rozleciały się w przestrzeni rojem złotych pszczół [...], nadpłynął zapach lip, zaszumiało [...] pradawną puszczą piastowską, zakołysały się zboża na polach, od których ojczyzna wzięła imię, zapachniało ziarnem $[\ldots]^{47}$.

Gdzie indziej pojawią się — dosłowne i symboliczne — mapy kraju: ta wisząca $\mathrm{w}$ wojennej Warszawie nad łóżkiem syna: „Widok mapy był bolesny. [...] Wielka zielona przestrzeń naszych równin [...]. Cała obrzeżona czerwonym pasem granicy, jakby arterią purpurowej krwi" 48 ; i ta podjęta z pola bitwy w postaci strzępu mapy wojskowej, przechowana z narażeniem życia niczym talizman, źródło kolejnej mitoopowieści:

Nazwy [...] zdarzały się te same co w bulli gnieźnieńskiej [...], parę brzmiało tajemniczo, jak wołanie z niewiadomego czasu. Był to głos mego plemienia. [...] Z wizerunku ziemi ojczystej, z rozproszonych dźwięków [...] wywinęła się opowieść o czasach pierwszych osadników, nieprzetartej puszczy i pachniało to pniem ściętego drzewa, skórą niedźwiedzia, smołą [... $]^{49}$.

45 To utwór prezentujący, jak pisał Stefan Zabierowski, „, co najmniej dwie konkurencyjne skale wartości — narodową i uniwersalną — bez zdecydowanego opowiedzenia się za jedną przeciw drugiej. Raczej sugerujący ich wzajemny związek. [...] bardziej zmuszający do refleksji niż dający gotowe i jednoznaczne rozwiązanie” — idem, Jan Parandowski — ,Godzina śródziemnomorska”. (Próba interpretacji), „Ruch Literacki” 1984, z. 4, s. 280.

46 J. Parandowski, Wrześniowa noc, Warszawa 1965, s. 85.

47 J. Parandowski, Powrót do życia, Warszawa 1972, s. 68.

48 J. Parandowski, Wrześniowa noc..., s. 37.

${ }^{49}$ Ibidem, s. 61. 
Można w tym widzieć ślady romantycznej historiografii, jak chce jeden z krytyków, choć prawdopodobne jest też echo Żeromskiego, którego Parandowski podziwiał za „wiedzę geologa i historyka, etnografa i lingwisty”, za to, że „miał w sobie ukrytą mapę Polski" 50 .

Jeśli w wojennym kodzie polskości do głosu dochodzi patos — „pełna uwielbienia apoteoza Warszawy" ${ }^{1}$, której los przypomina spalenie Rzymu przez Galów - zostaje wystylizowany na wzorce antyczne, nie romantyczne. Nie przypadkiem nazwano Parandowskiego „retorem”, ujmującym dany temat „według tradycji dawnych retoryk" 52 .

Ciekawym potwierdzeniem dystansu wobec tradycji sarmackiej jest krytyczny wizerunek ziemiaństwa. Archetypiczna przestrzeń dworu, wojennego azylu, skrywa niezbyt sympatycznych mieszkańców. Ich sybarycka, codzienna krzątanina razi protagonistę, a negatywną tradycję uobecnia groteskowa sylwetka zdziecinniałego starca o wyglądzie rasowego „hetmana”: „Kilkaset lat władzy zapewniło temu kręgosłupowi wytrzymałość, i stary nie chodzi pochylony, ponieważ jego przodkowie zawsze zadzierali głowę"53. Jedynie nimb walki uszlachetnia to środowisko. Nocna wizyta akowców we dworze zostaje ukazana z sentymentem, choć nie bez chłodnej refleksji — „Wiekuisty obraz polski: żołnierze, powstańcy, niecierpliwe konie, noc ocierająca się o brzask i kobieta z błogosławieństwem na ustach" "54. Fakt, iż powieść powstała w ogniu propagandy socjalistycznej, sugerowałby konformizm autora, ale Parandowski ze swoją inteligencko-mieszczańsko-ludową tożsamością mógł być szczery.

\section{Po 1945 roku — ojczyzny zastępcze}

Kontekst powojenny nie przyniósł wyraźnie nowych kodów polskości. Intensyfikacja wcześniejszych następuje w Alchemii słowa (1951) oraz Zegarze stonecznym (1953) — najbardziej znanych i cenionych w niemitologicznym

${ }^{50}$ Zob. J. Parandowski, Luźne kartki, Wrocław 1965, s. 37-38; J. Prokop, op. cit., s. 486.

${ }^{51}$ W. Studencki, op. cit., s. 71.

52 J. Prokop, op. cit., s. 487. Zob. też J. Parandowski, Wrześniowa noc..., s. 69-70, 78.

53 J. Parandowski, Powrót do życia ..., s. 114. Podobnych komentarzy jest więcej w twórczości pisarza, aczkolwiek powojenne są najostrzejsze: „Razem z kontuszami poodpadały buńczuczne miny i tak samo, jak przystrzyżono pokrętne wąsy, duszom przycięto rogów. [...] poznali, jak niewiele znaczą ze swoimi włościami [...] i z nazwiskami"; nauczycielka francuskiego na tajnych kompletach „uważała za ironię losu”, że ,jej najlepszym uczniem był syn chłopa”-ibidem, s. 24 25, 91; komentarz do lektury Defoe: „wolne mieszczaństwo - paskudne niewątpliwie, ale zapobiegliwe i skrzętne. [...] Nasza szlachta nie dusiła grosza, ale dusiła ludzi — chłopów i mieszczan i była jeszcze bardziej paskudna, a przy tym bardziej tępa" — idem, Luźne kartki..., s. 71. Bohater Nieba w płomieniach potępiał skąpstwo księżnej Sapieżyny, „cudzoziemki w narodzie”, ale radca korygował: „trzeba robić rachunek w całości. [...] może jej ojciec dał połowę majątku albo i własną krew. Bardzo wątpię, czy o naszej rodzinie dałoby się coś takiego powiedzieć" — DW I, 505-506.

54 J. Parandowski, Powrót do życia..., s. 134-135. 
dorobku autora. Nie sposób rozstrzygnąć, czy poszukiwanie małych ojczyzn powroty w świat dzieciństwa oraz krążenie w rejonach sztuki słowa, ojczyzny-polszczyzny ${ }^{55}$ - to tylko rezultat tykania zegara biologicznego, czy też miał tu swój udział kontekst polityczny. Nie warto również powtarzać wielokrotnych interpretacji wspomnień lwowskich, które wraz z Niebem $w$ płomieniach tworzą mikrokosmos dzieciństwa, w którym faktycznie „ojczyzna nie jest abstrakcją”. Można tylko przytoczyć deklaracje lwowskiego patriotyzmu z mniej znanych utworów: „ta ziemia, która pachnie jak żadna inna na świecie”; „cudowne miasto mojego dzieciństwa, powiązane tysiącem włókien, które niosły każdą nowinę, każde słowo po wszystkich ulicach i domach”; „oddawali tym murom [Ossolineum - A.M.] [...] najlepsze, co mieli w życiu — swoje szlachetne namiętności. Kochali namiętnie Polskę, wiedzę, poezję, książki, tradycję"56.

W kontekście małej ojczyzny nasuwa się pytanie o nieobecne u Parandowskiego sąsiedztwo polsko-ukraińskie. Psychoanalityk czy lacanowski politolog szukałby zapewne wyparcia podwójnego tabu — rodzinnego i politycznego, podczas gdy dekonstrukcjonista thumaczyłby to kompleksem lwowianina, orientalnego prowincjusza, wobec śródziemnomorskiego centrum ${ }^{57}$. Poprzestanę na konstatacji estetycznego désintéressement wobec ukraińskości u autora Mitologii oraz na wymienieniu jednego wyjątku. Pochodzi on z przedwojennego jeszcze tomu Trzy znaki zodiaku, zawierającego także teksty szkolnych czytanek ${ }^{58}$. Poczajów to jedna z nich — stylizowana na legendę powiastka o cudownym objawieniu Matki Boskiej, które ocaliło okolicę przed Turkami, lecz także żartobliwa przypowieść o diable-dezerterze znad Horynia, któremu znudziło się sprowadzanie krwawych najazdów. Finałowa, ruska pieśń lirnika jest ewenementem w twórczości pisarza. Herbert, najwspanialszy z uczniów Parandowskiego, nigdy się nie przemógł, by odwiedzić „zrabowane miasto ojców"59 i nigdy nie wszedł głębiej w relacje polsko-ukraińskie. W wypadku starszego o pokolenie pisarza mogło być podobnie — tym bardziej że już w latach trzydziestych oddał swe serce Warszawie.

${ }^{55}$ Na przykład szkice Dar „Popiołów” lub Pierwszy siew mowy polskiej, gdzie pojawia się pochwała Psatterza Floriańskiego: „W tych kilku tysiącach zdań zawiera się substancja, z której wykwitnie natchnienie Kochanowskiego, Skargi, Mickiewicza, Słowackiego" - Wis, 186-187.

56 J. Parandowski, Akacja..., s. 73; idem, Ztota nić..., s. 133; Wis, 122.

${ }^{57}$ R. Szczerbakiewicz, op. cit., s. 356, passim. Badacz trafnie zauważa nieobecność „galicyjskich Rusinów” w twórczości Parandowskiego, nie wiadomo jednak, dlaczego pisze o ich „niesprawiedliwym obrazie" - ibidem, s. 475.

58 Jak podkreślał pisarz z dumą, zamawianie tekstów czytanek u współczesnych literatów było nowatorskie i stawiane w owym czasie za wzór dydaktyczny w innych krajach.

59 Z. Herbert, Rovigo, Wrocław 1993, s. 59. Pewnym - ironicznym znów — komentarzem do polsko-ukraińskich animozji w końcu XIX wieku może byc uwaga o szkolnej dekoracji z widokiem Lwowa, ,skróconym jednak o katedrę św. Jura, czy to że zabrakło dla niej miejsca, czy też uznano, że arcydzieło generała Witta może wywierać wrażenie niepolityczne” (DW I, 672). 


\section{„Pośmiertna polskość” Parandowskiego}

Wiedza o tym, komu Jan Parandowski oddał swe serce i rękę przed zawarciem ślubu opisanego w noweli Corso, wyszła na jaw stosunkowo niedawno. Trop zapoznanej, podolsko-warszawskiej, pierwszej (,,polskiej”60) żony pisarza Aurelii Wyleżyńskiej (1881-1944) może być dobrym podsumowaniem pełnej niespodzianek biografii rzekomego olimpijczyka. Ze starszą od siebie pisarką Parandowski związał się podczas przymusowej ewakuacji w Saratowie, gdzie w latach 1916-1918 razem współorganizowali polskie życie kulturalne, kontynuując takie działania po powrocie we Lwowie. To jej młody Parandowski dedykował swoje spisane na gorąco studium o bolszewizmie ${ }^{61}$. Wydane niemal osiemdziesiąt lat po pierwodruku było także zaskoczeniem; nie kojarzono parnasizującego klasyka z rewolucją roku 1917 - wydarzeniem tak fundamentalnym dla najnowszych dziejów Polski - a jednak był on jego naocznym świadkiem i jako pierwszy podjął się ,próby syntezy”62. Pozostając przez dziesięciolecia nieznanym autorem Bolszewizmu i bolszewików w Rosji, wpisał się tym samym w trudny, pełen meandrów nurt polskości dwudziesto(pierwszo)wiecznej, której najbardziej fascynujących i dramatycznych perypetii nie dane mu już było oglądać.

$$
* * *
$$

Nie był oryginalnym czy przewrotnym (co dzisiaj jest tak w cenie) użytkownikiem kodów polskości. Jan Parandowski był pokornym uczniem tradycji - po prostu humanistycznej, gdyż nie odróżniał jej polskiego wnętrza od europejskiego zewnętrza. Jak wyznawał w kontekście wiersza Kasprowicza:

${ }^{60}$ Opozycja — opuszczona żona Polka oraz jej szczęśliwa rywalka Żydówka (czyli druga żona pisarza, Irena Heizel/Helcel) — dochodzi do głosu w dzienniku Wyleżyńskiej, która swoją pomoc udzielaną Żydom podczas okupacji komentowała następująco: „,niosę pomoc specjalnie tym, z rodu których spadło na mnie, przez jedną wybrankę, wielkie nieszczęście" — cyt. za: G. Pawlak, Aurelia (Aura) Wyleżyńska - zapomniana pisarka i publicystka. Materiaty do biografii, „Pamiętnik Literacki” 2014, z. 1, s. 165. Po rozstaniu z Parandowskim w 1924 roku Aurelia Wyleżyńska przebywała kilkanaście lat w Paryżu, była autorką kilku powieści i kilkuset artykułów. Okupację spędziła w Warszawie, gdzie jako pracownica warszawskich szpitali padła ofiarą niemieckiego ostrzału w pierwszych dniach powstania. Dopiero teraz planuje się wypełnić jej testamentalną wolę i wydać wojenny dziennik, który prowadziła świadomie z narażeniem życia, w celu pozostawienia świadectwa.

${ }^{61}$ Bolszewizm i bolszewicy w Rosji (1919) był najwcześniejszą, cenną i wnikliwą próbą opisu komunistycznego eksperymentu; ,raport Parandowskiego [...] we wnioskach przypomina Orwella" — J. Łukasiewicz, Notatki literackie, „Odra” 2008, nr 11, s. 51.

62 J. Parandowski, Bolszewizm i bolszewicy w Rosji, Londyn 1996, s. IV. „Mamy nadzieję, że wydanie tej pracy [...] pozwoli — być może - wyrwać pisarstwo autora Mitologii z uporczywie przez lata powielanych stereotypów [...] »olimpijskości« i »klasycyzmu«" — Od wydawcy, [w:] J. Parandowski, Bolszewizm i bolszewicy..., s. 197. Wydania krajowe: Stanisławów [1919], Warszawa 2007. 
niewiele stronic zebrałoby się z moich pism, gdzie to najdroższe słowo: ojczyzna pojawia się w orszaku innych słów [...], można by powiedzieć, że szedłem na dalekie, jakby obce drogi, gdzie nie było śladu polskiej stopy. [...] dla mnie to się inaczej przedstawia: Polska była i jest dla mnie zawsze nieodłączną częścią tej kultury, która ukształtowała nasz świat [...]. Wszędzie ją niosłem ze sobą $[\ldots]$, jest rdzeniem mojej istoty, nie umiem myśleć inaczej jak przez nią $[\ldots]^{63}$.

\section{Bibliografia}

Godzina śródziemnomorska, „Studia Classica et Neolatina”, t. 2, Gdańsk 1995.

Herbert Z., Rovigo, Wrocław 1993.

Kossewska E., Hebrajski przektad „, Mitologii”. Listy Jana Parandowskiego, Dawida Lazera i Dawida Ben Guriona, „Pamiętnik Literacki” 2018, z. 2.

Lichański J.Z., Wtajemniczenia i refleksje. Szkic monograficzny o Janie Parandowskim, Łódź 1986.

Łukasiewicz J., Notatki literackie, „Odra” 2008, nr 11.

Okoń J., Sarbiewski a Parandowski - dwie rocznice, dwie tradycje, „Ruch Literacki” 1996, z. 4.

Parandowski J., Akacja, Warszawa 1967.

Parandowski J., Bolszewizm i bolszewicy w Rosji, Londyn 1996.

Parandowski J., Dzieła wybrane, t. 2-3, Warszawa 1957.

Parandowski J., Luźne kartki, Wrocław 1965.

Parandowski J., Luźne kartki, wyd. 2 rozsz., Wrocław 1967.

Parandowski J., Podróże literackie, Wrocław 1968.

Parandowski J., Pod zamkniętymi drzwiami czasu, Warszawa 1975.

Parandowski J., Podróże literackie, Wrocław 1968.

Parandowski J., Polska leży nad Morzem Śródziemnym, „Przegląd Polski - Polish Review” 14.12.1989.

Parandowski J., Powrót do życia, Warszawa 1972.

Parandowski J., Wrześniowa noc, Warszawa 1965.

Parandowski J., Wspomnienia i sylwety, Wrocław 1969.

Parandowski J., Zlota nić, Kraków 1988.

Parandowski P., Mitologia wspomnień, Warszawa 2008.

Pawlak G., Aurelia (Aura) Wyleżyńska - zapomniana pisarka i publicystka. Materiały do biografii, „Pamiętnik Literacki” 2014, z. 1.

Prokop J., Prozaicy dwudziestolecia międzywojennego. Sylwetki, red. B. Faron, Warszawa 1974.

Studencki W., Alchemik stowa. Rzecz o Janie Parandowskim, cz. 2, Opole 1974.

Susuł J., Jan Parandowski, „Tygodnik Powszechny” 1967, nr 30.

Szczepkowska J., Rozmowa śródziemnomorska, „Rzeczpospolita” 2013, nr 301.

Szczerbakiewicz R., „,Niepokalana szczerość jest urojeniem”. Dekonstrukcje mitu śródziemnomorskiego w twórczości Jana Parandowskiego, Lublin 2014.

Zabierowski S., Jan Parandowski — „Godzina śródziemnomorska”. (Próba interpretacji), „Ruch Literacki" 1984, z. 4.

63 J. Parandowski, Luźne kartki, wyd. 2 rozsz., Wrocław 1967, s. 88. 


\title{
Mediterranean codes of Polish identity in Jan Parandowski's work
}

\begin{abstract}
Summary
One is used to regarding Jan Parandowski (1895-1978) as a great connoisseur of the ancient world and a kind of "Olympic" writer with a distance to his own time and space. A thorough examination of his literary essays, short stories and novels hardly proves this opinion. Treating Polish history and culture, especially of the Renaissance epoch, as originating from and inspired by the ancient Roman/Greek tradition ("Poland is situated in the Mediterranean"), he conceals at the same time an evidently emotional approach to national legacy. There are several modes in which he evokes unique Polish history in the 19th century, with the great but problematic heritage of Romanticism as well as the controversial destiny of modern Polish artists obliged to fulfil national duties; he describes in classically discreet style Polish war experiences; he creates in different ways a sentimental image of his lost home country in Lwów. One of the clearest manifestos of the writer's involvement in Polish identity can be also found in his defence of national sentiments and their qualities against the attitude presented in the famous work La Trahison des clercs (The treason of the intellectuals) by Julien Benda. According to Parandowski's own declaration, his patriotism was responsive to aesthetical and sensory epiphany (geographical, landscape, etc. impressions) rather than to some abstract national symbols and declarations. There is also a close, mutual correspondence between ancient impulses in his work and his biography (Polish history); the writer has been frequently seeking for any consolation in Mediterranean utopian dimensions. Last but not least, the "postmortal" testimony of Polish identity in Parandowski's biography and work seems to be related to the experience - for a long time unknown and only recently revealed — during his exile in revolutionary Soviet Russia; his pioneering study about "Bolshevism" documents the history of 20th-century totalitarianism and definitely denies the allegedly apolitical mind-set of the "Olympian."
\end{abstract}

Keywords: Jan Parandowski, history, ancient tradition, Polish identity, Romanticism 